\title{
A PAISAGEM ACRE ÁCIDA AZEDA DE MARCELO DOLABELA
}

Mário Alex Rosa*

Marcelo Dolabela há muitos anos vem publicando seus livros de poemas, CDs de poesia, artigos e realizando exposições de objetos e coleções de vinis de forma quase sempre "clandestina". Além disso, sempre organizou jornais, revistas, eventos culturais na área artística de Belo Horizonte. Postura que nos parece radicalmente afinada com suas posições políticas, seja na cena literária, ou mesmo cultural Quem teve acesso aos seus livros, como o ótimo livro-objeto Hai kaixa (1993), no formato de uma caixa de fósforos, contendo 100 haicais, poderá confirmar essa postura criteriosa do poeta e ativista.

A confirmação dessa postura vem com a publicação de um novo livro ACRE ÁCIDO AZEDO (2015), assim sem pontuação. De formato modesto, independente e com tiragem de apenas 200 exemplares. Com um título acentuadamente negativo
* malexrosa@gmail.com

Doutor em Literatura Brasileira pela USP, editor e poeta, autor dos Clube e outros poemas, Ouro Preto e Via Férrea.

ao repetir três substantivos/adjetivos da mesma "família", como se quisesse reforçar toda acidez que o leitor encontrará nos 50 poemas. Como se não bastasse o sentido individual de cada palavra, o poeta reafirma a repetição dos seus significados que se acentuam, ou melhor, multiplicam-se os seus sentidos. Portanto, esse excelente livro, requer um olhar mais vagaroso na sua acidez lírica.

Quase em sua totalidade, os poemas são metrificados, decassílabos, predominando a forma do soneto com suas exigências estróficas e rimas internas, ainda que em um ou em outro a regra seja quebrada, mas sem dúvida é proposital, como, por exemplo, o desvio de um acento ou da pontuação. Aliás, esses desvios não só afirmam o domínio de Marcelo Dolabela sobre o assunto como também demonstram o rigor e o cuidado que dá aos seus sonetos. É importante dizer 
que o poeta ao usar formas fixas não está fora do contexto contemporâneo da poesia brasileira, que, atualmente, parece um vale tudo, como se o conhecido verso livre fosse a razão e a tônica do momento, e o poeta que utilize de outras formas é chamado de passadista. Ora, quase todos os poetas modernistas que utilizaram o verso livre, posteriormente mostraram o total domínio sobre a forma fixa, como fez Carlos Drummond, nos anos 1950, com o conhecido livro Claro Enigma. Mais recente, temos o poeta Paulo Henriques Britto que utiliza de formas canônicas (decassílabos, alexandrinos), porém com uma linguagem coloquial, digamos assim, para a fatura dos seus poemas. Seja em Dolabela ou Henriques Britto, o uso dessas formas definitivamente não é para mostrar virtuosismo técnico como se a expressão do poema ficasse apenas e somente na forma. Muito pelo contrário, o modo que os dois poetas constroem alguns dos seus sonetos, seja com humor, ironia ou lirismo crítico, faz com que a fatura do poema fique bem equacionada entre forma e sentido. ACRE ÁCIDO AZEDO é, sem dúvida, a confirmação substancial desse encontro raro do poeta com sua expressão e "admiração pela técnica do verso e pelos conceitos e temas - "recorrentes" - da e na poesia", conforme escreve o poeta na contracapa do livro.

Mas para além da técnica, os poemas de Dolabela constituem uma escrita que procura rever não só os seus procedimentos técnicos, mas o modo como certos temas, desde sempre, o poeta costuma visitar: a condição precária do sujeito na lírica.

Desse ótimo livro, destaca-se a série de 17 poemas "Belo Horizonte, adeus" que aparece como uma alegoria da vida, por mais que que muitos dos poemas sugiram posturas mais negativas. Em "Belo Horizonte, adeus 2", escreve:

\section{Adeus cidade. Adeus tempo.}

Adeus estrada. Adeus lar.

Adeus tormenta. Adeus vento.

Adeus batalha. Adeus bar.

No entanto, a cada "adeus" dos poemas mais parece se reafirmar a relação dialética que o poeta tem com a cidade, afinal o paradoxo se instala, como no poema brevíssimo "Autobiografia dialógica e definitiva" que diz:

\section{$-. . . ?$}

- ando exilado

por aqui mesmo! ${ }^{2}$

Ora, o exílio aqui é também refletir a condição de sujeito lírico diante da cidade em que mesmo indiferente a sua presença, desde Baudelaire, na segunda metade do século XIX, o poeta sabe que na vida moderna ou pós-moderna a sua
2. DOLABELA, p. 11 (itálicos do poeta).
EM TESE
BELO HORIZONTE
v. 21
N. 3
SET.-DEZ. 2015
ROSA. A paisagem ACBE ÁCDA AZZDA de Marcelo Dolabela [resenha]
P. $188-190$ 
condição é um estar fora do lugar. No entanto, é dessa falta que o poeta constrói também a sua linguagem. Assim, se, por um lado, a cidade é motivo de adesão, de uma inspiração inquieta e que movimenta o poeta a concretizar formulações subjetivas, portanto de achatamento do sujeito diante do que lhe é indiferente. Por outro, esse mesmo sujeito parece saber que é dessa indiferença que ele vai desentranhar o que lhe falta, e que pode ser tudo. Nesse sentido, a lírica ácida de Dolabela ao expor a condição do sujeito na cidade reafirma, mais uma vez, como alguns poetas mantêm uma relação de adesão e negação ao falar do lugar onde nasceu ou passou a residir. A Belo Horizonte de Dolabela não é sua descrição, sua paisagem e seus contornos, muito menos uma crônica da cidade. O que se percebe é um sujeito lírico que se auto-avalia enquanto pensa sobre a cidade onde vive, como nesse soneto - "Belo Horizonte, adeus 15" -, cuja forma e sentido faz desse belo poema um guia de como se pode refletir sobre o processo de lapidação de uma escrita que em medida exata consegue condensar a difícil tarefa de não sentimentalizar a dor da partida:

Existem outras formas de morrer, mesmo fora do alcance da visão, fora dos gestos e da imensidão

corpórea de qualquer um, qualquer ser.

$\mathrm{Na}$ noite, bem antes do amanhecer, quando o sol não tragou a escuridão, se caminha, sem luz, com imprecisão, nesse temer cair ou se perder.

Ao meio-dia, existe outro escrever

com rubras letras, sobre a vastidão,

que faz de nós, pobres serpes, no chão,

que faz da vida não querer viver.

Não há regra, não há lei, é ilusão

supor que, na dor, se pode escolher. ${ }^{3}$

3. DOLABELA, p. 26.

Com esse livro severo, tratado com rigor de quem diz "não abro mão do que cunho,/ minha mão nasce no punho", ${ }^{4}$ só podemos celebrar esse poeta que revisa não apenas a sua trajetória histórica criadora, mas de um poeta que nesses mais de 30 anos militando na poesia e na cultura mineira, tem definitivamente o seu lugar no que já se fez de melhor nessa capital que ainda carece de reconhecer seus melhores poetas. ACRE ÁCIDO AZEDO é a confirmação de que ainda se pode fazer poesia com mãos firmes e sem badulaques.

\section{REFERÊNCIA}

DOLABELA, Marcelo. ACRE ÁCIDO AZEDO. Belo Horizonte: edição do autor, abr. 2015, $60 \mathrm{p}$ 